Charlotte Haug (f. 1959) er dr. med. og har en mastergrad i helsetjenesteforskning fra Stanford University. Hun har vært redaktør av Tidsskrift for

Den norske legeforening siden 2002.

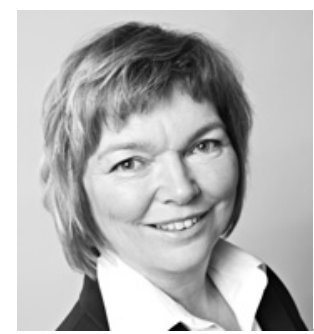

Foto Einar Nilsen

Vi har fått (enda) en ny rød-grønn helseminister.

Gjør han kort prosess og erklærer at foretaksreformen var et feilgrep?

\title{
Alt på ett kort
}

Errare humanum est, sed perseverare diabolicum Seneca, romersk filosof (4 f.Kr.-65 e.Kr.)

Det gikk som det måtte gå: Vi fikk enda en ny helseminister. Den fjerde på sju år. Bjarne Håkon Hanssen overtok etter Sylvia Brustad i 2008. Han trakk seg fra politikken året etter, han var ikke noen «gjennomfører» (av samhandlingsreformen). Det skulle Anne-Grete Strøm-Erichsen ta seg av: «Gjennomføringskraften var avgjørende i valget av helseminister. (...) Hun har en diskret autoritet som gjør henne i stand til å gjennomføre krevende prosesser,» sa en sentral kilde i Arbeiderpartiet til Aftenposten (1).

Nå går stafetten videre til Jonas Gahr Støre, Stoltenbergs sterkeste kort. Forventningene og forventningspresset er stort. Den offentlige helsetjenesten tåler ikke flere fagre løfter, kjappe løsninger og fine visjonsdokumenter og powerpointpresentasjoner. Den tåler ikke mer tåketale, ansvarsfraskrivelse og gjensidige beskyldninger. Og den helt nødvendige tilliten mellom pasienter, pårørende, helsepersonell, ledere og politikere må gjenopprettes veldig raskt. Hvis ikke er prognosen for den norske helsetjenesten slik vi har kjent den, særdeles dårlig.

Støre er en av norsk politikks best skolerte. Han har utdanning både fra Norge, Frankrike og USA. Han var medforfatter av boken Scenarier 2000 da han var midt i 20-årene (2). Fra han var knapt 30 år og i nesten ti år var han en sentral politisk bakspiller. Som spesialrådgiver og senere ekspedisjonssjef ved statsministerens kontor ble Støre beskrevet som kunnskapsbanken, idémakeren og strategen som bidro med analyser, premisser og vurderinger til fire forskjellige statsministre. Både Høyre og Arbeiderpartiet ønsket ham på sitt lag, siden han ikke hadde flagget partipolitisk ståsted. Da Gro Harlem Brundtland ble direktør i WHO, tok hun ham med seg og gjorde ham til sin viktigste rådgiver. Det var altså ingen politisk novise Jens Stoltenberg hentet hjem til Norge for å bli stabssjef ved statsministerens kontor da han dannet sin første regjering i mars 2000. Og nettopp erfaringen fra Stoltenberg I-regjeringen kan vise seg å være den aller nyttigste for den nye helseministeren. For hva skjedde? Mindretallsregjeringen ønsket å modernisere offentlig sektor etter inspirasjon fra næringslivet - med helsesektoren som selve prestisjeprosjektet. Tore Tønne ble hentet inn som helseminister direkte fra Norway Seafoods som omstillingsekspert og «feltfremmed strateg», som Rune Slagstad så glimrende beskrev i en kronikk i Tidsskriftet nylig (3).

Helseforetaksreformen ble gjennomført på rekordtid av noen ganske få personer med Tore Tønne, statsministeren og hans meget dyktige stabssjef Jonas Gahr Støre i førersetet. De involverte svært få andre i prosessene og var ikke særlig åpne for motforestillinger.

Intensjonene var prisverdige: Alle skulle få bedre, mer tilgjengelige og mer likeverdige helsetjenester. Fellesskapets ressurser skulle utnyttes bedre. Men som jeg bemerket $i$ en lederartikkel rett etter at sykehusreformen ble vedtatt i 2001 (4): «For pasienter er ikke gode intensjoner eller hvem som eier sykehuset det avgjørende. Det avgjørende er hvem som tar de endelige beslutningene om behandling og hvilken pleie pasientene får.» Her var Tore Tønnes redegjørelse for Stortinget tindrende klar: «(Reformen) vil ha umiddelbare og langsiktige konsekvenser for ansvar og ansvarsutøvelse, for rollefordeling mellom ulike aktører, og for mulighetene til videre utvikling av en av de viktigste sektorer i samfunnet» (5). Det ble også problematisert at «profesjonene har fått for fritt spillerom» (6, s. 30). Reformen flyttet makt fra politikere, pasienter og helseprofesjoner til de nye foretaksstyrene. Hvordan disse ville prioritere var derfor det store spørsmålet.

Nå, 11 år etter, ser vi resultatene. Noe er blitt bedre (mange sykehus har fått orden på regnskapene), men mye er blitt verre. Det skumleste er at de høylytte protestene fra de mest engasjerte, kompetente og ansvarsbevisste blant leger og annet helsepersonell begynner å stilne. Stadig flere av dem som kan, går over til det private. Det er altfor enkelt å påstå at de gjør det for pengenes skyld. De fleste gjør det fordi de finner det mer meningsfylt (7). De som hørte og så en alvorstynget og tydelig sliten overlege Christian Grimsgaard i TV-debatt 17.9. skjønte godt hva det dreide seg om: «Det er veldig mange resignerte medarbeidere, vi mister mange gode, og vi får kanskje ikke de søkerne vi helst ville ha.» Noen vil gjøre dette til et Oslo-problem, men det blir for enkelt. Til nå er det bare i Oslo det er reelle exitmuligheter. Men flere kan følge.

Den største trusselen mot et offentlig, solidarisk finansiert helsevesen er ikke private alternativer - hovedtrusselen er et offentlig helsevesen som forvitrer. Ikke av mangel på penger, men av mangel på sans for hvor viktig personlig engasjement, faglig selvrespekt og vilje til å ta selvstendig ansvar er. Mye farligere enn mangel på penger er det hvis kompetanse ikke anerkjennes og den enkeltes innsats ikke verdsettes.

«Står vi fast på gamle løsninger som ikke virker, da svekker vi tilliten til fellesskapsløsningene. Da svekker vi velferden og øker ulikhetene. Det taper vi alle på,» sa Stoltenberg i regjeringens tiltredelseserklæring på Stortinget 22. mars 2000. Alt tyder på at mange av de løsningene som er valgt for å løse de høyst reelle problemene i spesialisthelsetjenesten de siste 15-20 år nå faller i kategorien «gamle løsninger som ikke virker»: Innsatsstyrt finansiering førte raskt til kodejusteringer og -triksing. Samhandlingsreformen er så uklar at man knapt vet hvordan den skal vurderes. Foretaksreformen er blitt et system for ansvarsfraskrivelse, ikke for ansvarsplassering. Dette har Stoltenberg og Støre observert fra orkesterplass.

Både Cicero og Seneca er tillagt utsagnet det er menneskelig å feile, men djevelsk å fortsette å feile. Helseministeren kjenner det nok.

Litteraturlisten finnes på www.tidsskriftet.no 